\title{
New dicoumarol sodium compound: crystal structure, theoretical study and tumoricidal activity against osteoblast cancer cells
}

\author{
Sadia Rehman ${ }^{1,2}$, Muhammad Ikram², Ajmal Khan ${ }^{3}$, Soyoung Min ${ }^{4}$, Effat Azad ${ }^{4}$, Thomas S Hofer ${ }^{3}$, KH Mok ,
} Robert J Baker ${ }^{5}$, Alexander J Blake ${ }^{6}$ and Saeed Ur Rehman ${ }^{1}$

\begin{abstract}
Background: Enormous interest had been paid to the coordination chemistry of alkali and alkaline metal ions because of their role inside body viz; their $\mathrm{Li}^{+} / \mathrm{Na}^{+}$exchange inside the cell lead to different diseases like neuropathy, hypertension, microalbuminuria, cardiac and vascular hypertrophy, obesity, and insulin resistance. It has been presumed that alkali metal ions (whether $\mathrm{Na}^{+}$or $\mathrm{K}^{+}$) coordinated to chelating ligands can cross the hydrophobic cell membrane easily and can function effectively for depolarizing the ion difference. This unique function was utilized for bacterial cell death in which $\mathrm{K}^{+}$has been found coordinated valinomycin (antibiotic).

Results: Distinct sodium adduct (1) with dicoumarol ligand, 4-Hydroxy-3-[(4-hydroxy-2-oxo-4a,8a-dihydro-2H-chromen3-yl)-phenyl-methyl]-chromen-2-one (L) is isolated from the saturated solution of sodium methoxide. Single crystal $X$-ray diffraction studies of the adduct reveals that sodium is in the form of cation attached to a methoxide, methanol and a dicoumarol ligand where carbonyl functional groups of the coumarin derivative are acting as bridges. The sodium compound (1) is also characterized by IR, ${ }^{1} \mathrm{H}-\mathrm{NMR}$, and ${ }^{13} \mathrm{C}\left\{{ }^{1} \mathrm{H}\right\}-N M R$ spectroscopic techniques. The composition is confirmed by elemental analysis. DFT study for 1 has been carried out using B3LYP/6-13G calculations which shown the theoretical confirmation of the various bond lengths and bond angles. Both the compounds were studied subsequently for the U2OS tumoricidal activity and it was found that $L$ has $L D_{50}$ value of $200 \mu M$ whereas the sodium analog cytotoxicity did not drop down below $60 \%$.
\end{abstract}

Conclusion: A sodium analogue (1) with medicinally important dicoumarol ligand (L) has been reported. The crystal structure and DFT study confirm the formation of cationic sodium compound with dicoumarol. The ligand was found more active than the sodium analog attributed to the instability of 1 in solution state. Coumarin compound with sodium was observed to be less cytotoxic than the ligand, its $\mathrm{LD}_{50}$ value never dropped below $60 \%$.

Keywords: Dicoumarol, Sodium cation, Single crystal study, DFT, Bone cancer

\section{Findings}

This work is dealing with the synthesis of sodium derivative of dicoumarols. The structure was assigned based upon the single crystal diffraction and DFT studies. It was presumed that the novel sodium compound will show very good results in biological system but the opposite behavior was observed owing to the instability of the compound in solution phase. We are searching for

\footnotetext{
* Correspondence: ikram.chemistry@suit.edu.pk

${ }^{2}$ Department of Chemistry, Sarhad University of Science and Information Technology, Peshawar, Pakistan

Full list of author information is available at the end of the article
}

the possible answers in this unique research and soon will be available to the reader.

\section{Background}

In malignant sarcoma the neoplasm of the malignant tissues produces malignant osteoid which causes bone cancer. This is prevailing 4 in 100,000 people/year and is a leading cancer disease in children's under age 15. Leg or hand amputation, a disaster to the human or animal body, is caused by osteosarcoma [1].

There are different types of sarcomas including the synovial sarcoma, Ewing's sarcoma and osteosarcoma which

\section{(Chemistry Central}


are more often found in young adults and neoplasias such as leiomyosarcoma or liposarcoma are found in humans of more than 55 years age [1,2]. Synovial sarcoma is being treated using doxorubicin and ifosfamide as shown in Scheme 1 [3].

The doxorubicin has been found to cause neutropenia, alopecia, dispigmentation, and reactivation of Hepatitis $B$, cardiomyopathy or even death. Therefore due to its very toxic nature it had been named as "Red Devil" [4-7]. Similarly ifosfamide causes encephalopathy (brain dysfunction), a very serious drawback of the drug. Encephalopathy is actually caused by the production of toxic side products like acetaldehyde and chloral hydrate [8].

Coumarin and its derivatives are biologically very active. It was found that the enhanced activities are dependent on the coumarin nucleus [8-12]. Biological significance of these compounds include anti-bacterial [12] antithrombotic and vasodilatory [13], anti-mutagenic [14] lipoxygenase and cyclooxygenase inhibition [15,16], scavenging of reactive oxygen species, and anti-tumourigenic [17-23]. The fact that such compounds have medicinal applications, prompted many researchers to work in this field and several recent reviews summarize advances in this field [24-29]. Coumarin and its derivatives have been applied for treatment of different types of cancers including malignant melanoma, leukaemia, renal cell carcinoma, prostate and breast cancer. Coumarin when applied in combination with radiotherapy and surgery as a chemotherapeutic agent provides best results. It, not only treat cancer but also decreases the side effects of radio therapy [30].

Coumarin and its derivatives have also been used in the treatment of Malignant Melanoma [23]. Initially the melanoma diagnosis involved surgical removal of primary lesion with the high risk of recurrence after five years. However the problem was minimized by the use of 4-hydroxycoumarin along with warfarin to maintain therapy and to inhibit the tumor spread. Therefore, 4hydroxycoumarins have been successful in adjuvant therapy for melanoma [31,32].

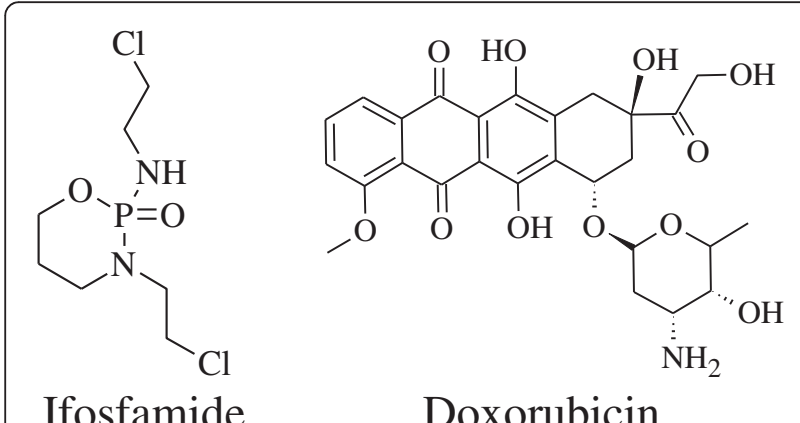

Scheme 1 Drugs for the treatment of synovial sarcoma.
Coumarin and its derivatives have been investigated for their possible use in the treatment of renal cell cancer $[33,34]$. In vitro effects of such compounds on the growth of renal cell carcinoma derived cell lines proved coumarin and 7-hydroxycoumarin as potent cytotoxic and cytostatic agent [35]. Similarly in case of other types, like leukaemia, prostate and breast cancer, cyclin $D_{1}$ is released in an amount more than the normal levels. Coumarin and its derivatives have been proved significant antiproliferative agents by regulating the release of Cyclin $\mathrm{D}_{1}$ [36-38].

Enormous interest had been paid to the coordination chemistry of alkali and alkaline metal ions because of their role inside body viz; their $\mathrm{Li}^{+} / \mathrm{Na}^{+}$exchange inside the cell lead to different diseases like neuropathy, hypertension, microalbuminuria, cardiac and vascular hypertrophy, obesity, and insulin resistance. It has been presumed that alkali metal ions (whether $\mathrm{Na}^{+}$or $\mathrm{K}^{+}$) coordinated to chelating ligands can cross the hydrophobic cell membrane easily and can function effectively for depolarizing the ion difference. This unique function was utilized for bacterial cell death in which $\mathrm{K}^{+}$has been found coordinated valinomycin (antibiotic). Alkali and alkaline metals ions complexed with many coordinating ligands like crown ethers, cryptands, pyrazolyl, nitriles, phosphanide and many others were studied previously [39-45].

In the recent report we have focused upon the modified coumarin and its sodium derivative, keeping in mind the aforementioned importance of coumarin nucleus. The modified coumarin has been prepared by reacting bezaldehyde with 4-hydroxycoumarin to yield the dicoumarol ligand. Efforts for deprotonating the hydroxyl groups, using the sodium methoxide, gave the disodium coumarin compound. The sodacation compounds has been studied structurally by X-ray crystallography, supported by DFT calculations and spectroanalytical techniques. The compounds were screened, In Vitro, for U2OS anticancer activities, presuming sodium derivatives will be more active than the parent ligand. However, the observed results were contradictory to our assumption, probably, due to the instability of sodium compound inside cell matrix. This aspect of the sodium compound may be further studied in detail to see the actual possible reason behind the presumed bahvior.

\section{Results and Discussion}

Crystal structure of $\mathbf{1}$, as shown in Figure 1 whereas Figure 2 represents the fragment of the sodium adduct with $\mathbf{L}$.

It is revealed by looking into the crystal structure of $\mathbf{1}$ that sodium cations are attached to the carbonyl oxygen $\mathrm{O}(6)$ $\mathrm{Na}$ at distance 2.414 $\AA$ while the bond length for sodium cation attached to carbonyl and lactone oxygen $\mathrm{O}(1)-\mathrm{Na}-\mathrm{O}$ (2) is $2.475 \AA$ showing trans tetragonal planar arrangement of the atoms in space. This behaviour is further proved by 


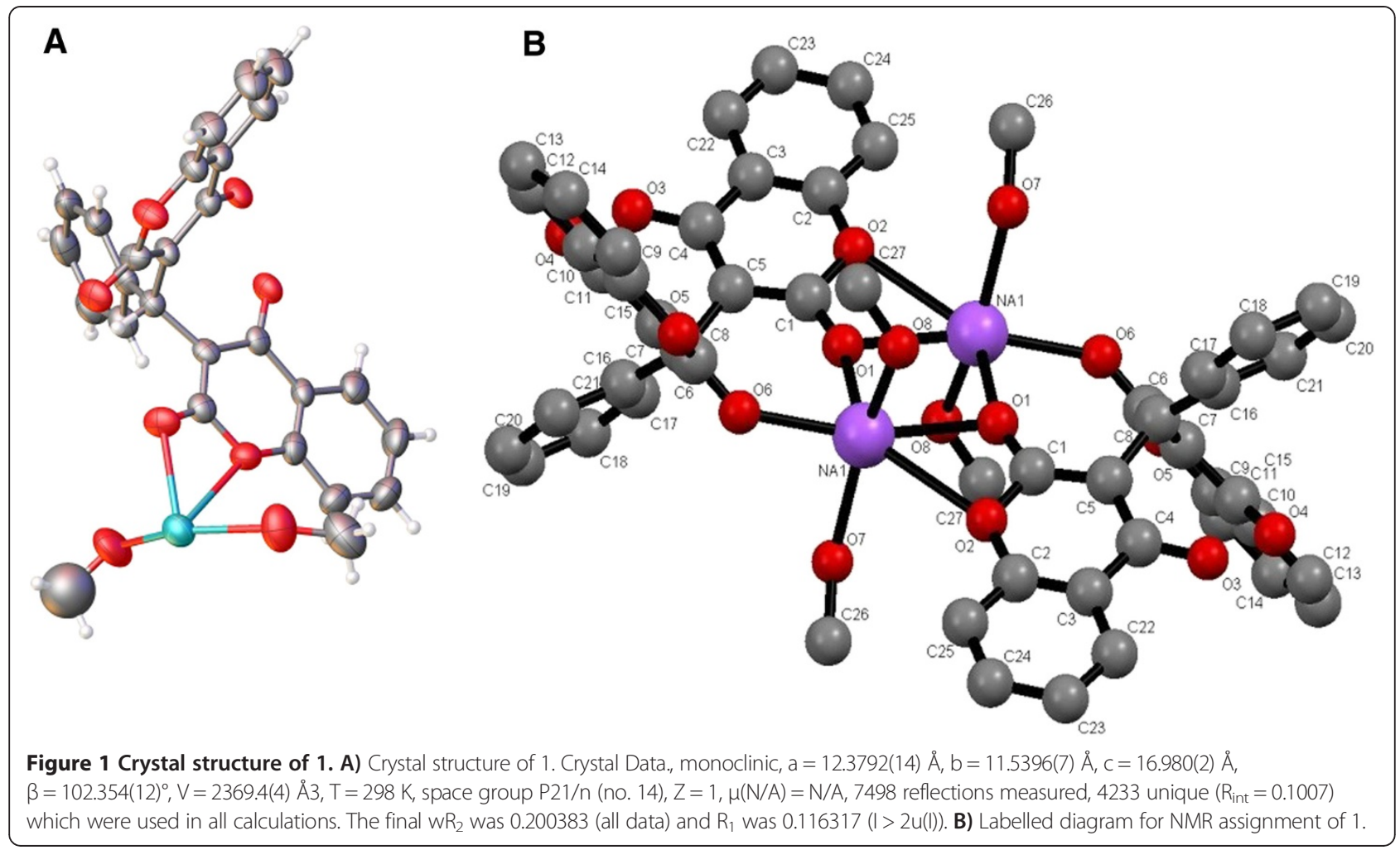

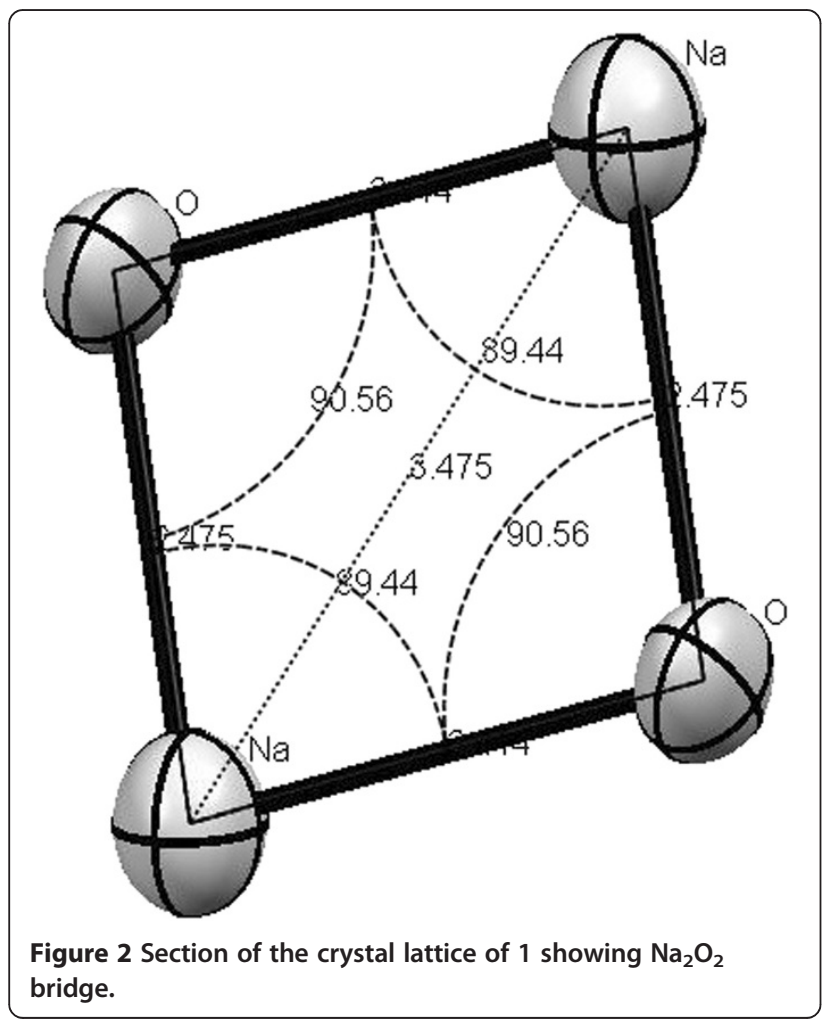

the bond angles pattern of the same $\mathrm{Na}_{2} \mathrm{O}_{2}$ plane where the bond angle of $\mathrm{O}(1)-\mathrm{Na}(1)-\mathrm{O}(1)$ is $89.44^{\circ}$ while the bond angle for $\mathrm{Na}(1)-\mathrm{O}(1)-\mathrm{Na}(1)$ is $90.56^{\circ}$ revealing coplanarity of the structure. Inter cationic distance between the two sodium cations is $3.441 \AA$. The bond distance for $\mathrm{C}=\mathrm{O}$ for the $\mathrm{C}(1)-\mathrm{O}(1)$ in 1 is $1.247 \AA$ while for $\mathrm{C}(8)-\mathrm{O}(6)$ is 1.199 $\AA$, the former is $0.048 \AA$ longer than the latter which may be attributed to the bond formation from the lactone oxygen. The bond distance for $\mathrm{O}(1)-\mathrm{Na}(1)$ is $2.873 \AA$ suggesting that the bond is weaker. By comparing the bond angles of $\mathrm{O}(7)-\mathrm{C}(1)-\mathrm{O}(1)$ and $\mathrm{O}(8)-\mathrm{C}(8)-\mathrm{O}(6)$ which are $112.5^{\circ}$ and $114.59^{\circ}$ respectively, suggest that $\mathrm{C}=\mathrm{O}\{\mathrm{C}$ (1)-O(1) \}angle is decreased by the bond formation between $\mathrm{O}(1)$ and $\mathrm{Na}(1)$. The bond distance $\mathrm{Na}(1)-\mathrm{O}(8)$ is $2.350 \AA$ identical for all the methoxide/methanol ions attached to the sodium. Sodium cation produces an eight membered ring with $\mathrm{O}(6)-\mathrm{C}(8)-\mathrm{C}(7)-\mathrm{C}(6)-\mathrm{C}(5)-\mathrm{C}(1)-\mathrm{O}(1)$ atoms. The plane produced by $\mathrm{Na}-\mathrm{O}-\mathrm{Na}-\mathrm{O}$ is separated by $20.04^{\circ}$ from the plane produced by $C(8)-C(7)-C(5)-C$ (1)- $\mathrm{Na}(1)$. If $\mathrm{C}(6)$ is included in the plane produced by chelate ring then the two planes are separated by a mean angle of $17.89^{\circ}$. Therefore, it shows that $C(6)$, due to the attached phenyl ring, does not lie in the plane produced by $C(8)-C(7)-C(5)-C(1)-N a(1)$. The DFT structural features were also studied.

Figure 3(A) clearly show the ligands coordination to the sodium cations. The hydrophobic sites are protruding out making it possible for the sodium compound to 

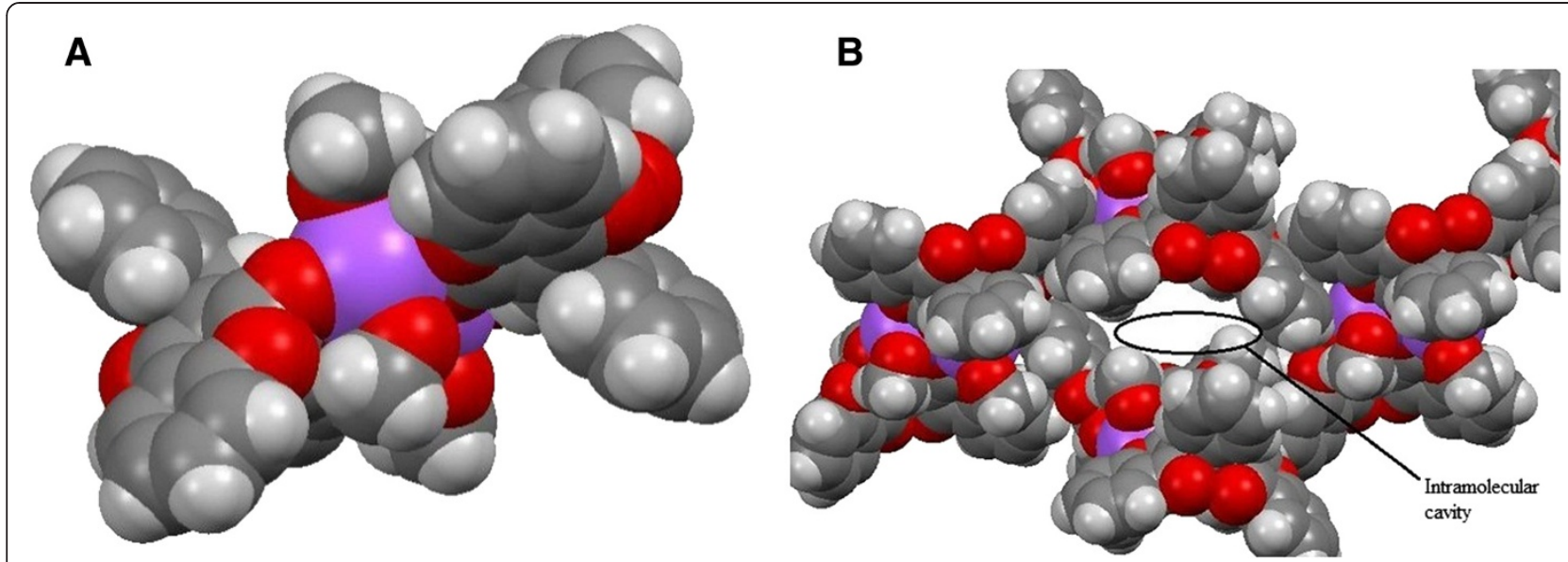

Figure 3 Space filled model of 1. A) Space filled model of 1. It has been shown here that sodium ions are embedded by dicoumarol ligands B) Wide geometric cavity.

cross the hydrophobic cell membrane. Large cavities can be seen in Figure 3B.

The IR spectrum of the ligand was assigned, the carbonyl stretching frequency in ligand was observed around $1647 \mathrm{~cm}^{-1}$ which may be due to hydrogen bonding [20] and it was displaced to $1671 \mathrm{~cm}^{-1}$ after complexation with sodium. The C-O phenolic vibration observed at $1303 \mathrm{~cm}^{-1}$ was also displaced to $1349 \mathrm{~cm}^{-1}$ by coordination with sodium.

${ }^{1} \mathrm{H}$ and ${ }^{13} \mathrm{C}\left\{{ }^{1} \mathrm{H}\right\}$-NMR results are also consistent with the structures obtained. ${ }^{1} \mathrm{H}-\mathrm{NMR}$ in DMSO- $d_{6}$ shows a singlet at $6.10 \mathrm{ppm}$ which was assigned to $-\mathrm{CH}(\mathrm{Ar})_{2}$ peak, whereas the aromatic protons are observed in the range of 7.20-7.90 ppm. The hydroxyl protons were not observed in the sodium complex. In ${ }^{13} \mathrm{C}\left\{{ }^{1} \mathrm{H}\right\}$-NMR the peak for the $\mathrm{CH}_{3}$ of the methoxide ions is observed at $103 \mathrm{ppm}$ because of coordination to sodium cations. Rest of the spectrum is almost identical to $\mathbf{L} .{ }^{23} \mathrm{Na}-\mathrm{NMR}$ was also recorded for the compound which shows a single peak at $-1.01 \mathrm{ppm}$ suggesting the presence of sodium cation.

Molecular ion peak was not observed in DMSO. Therefore elemental analysis was carried out which revealed the mentioned composition. The molar conductance value suggest the presence of free ions in the solution state, therefore it was concluded that the complex ionizes when dissolved. The DFT structural study had been carried out using Gaussian G09 at B3LYP/6-13G (d, p) level [46]. The minimum energy calculated from geometric optimization of Gaussian G09 at B3LYP/6-13G (d, p) level is -3612 Hatree. The geometrical optimized structure from Gaussian is similar to the single crystal structure in term of interatomic distances as well as in angles (Figure 4A and Figure 4B).

The theoretical structure for $\mathbf{1}$ was optimised inorder to get into the conclusion of correct structure for $\mathbf{1}$. The difference between the calculated and the observed bond

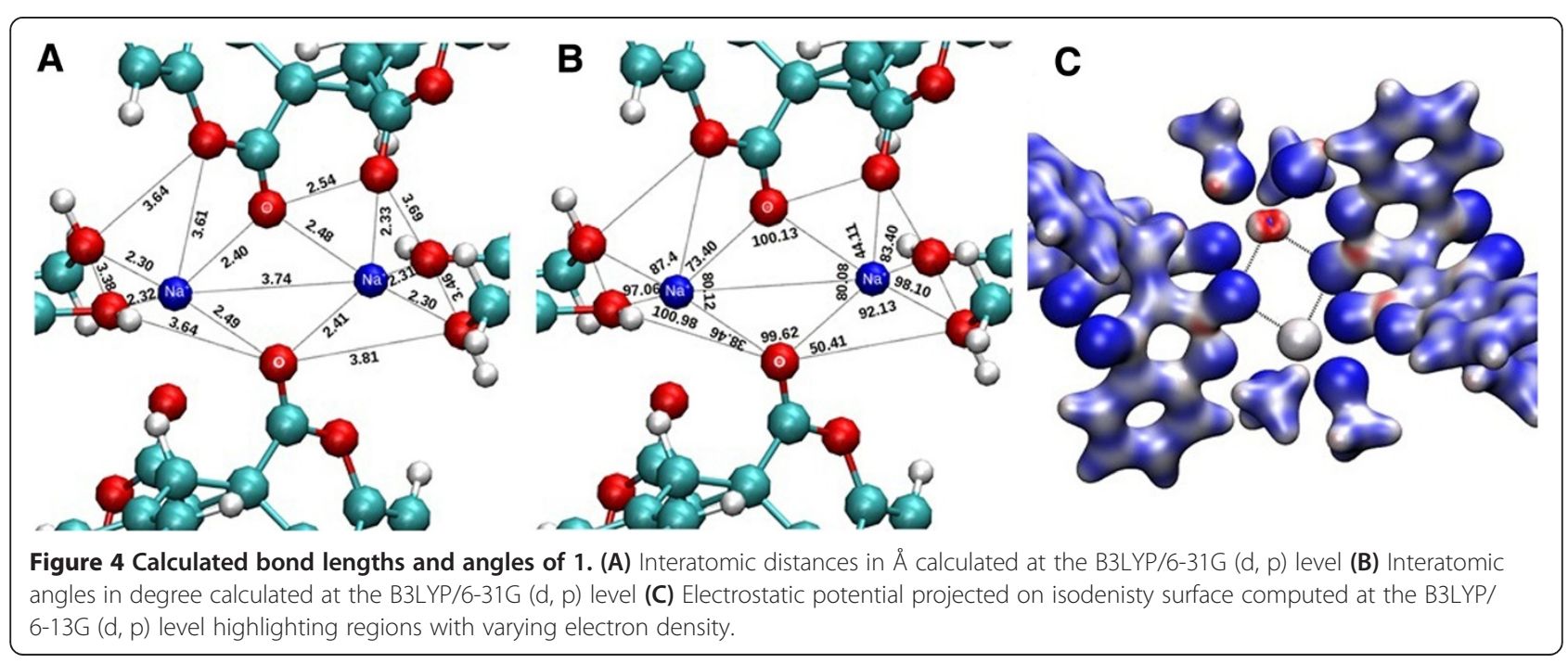


lengths and angles has been shown in Table 1, revealing that there is not much difference for the bond lengths but the bond angles are not so close, therefore it can be concluded that one of the methoxide ions is acting as neutral methanol molecule.

The electrostatic potential projected on isodensity surface computed at B3LYP/6-31G /d, p) is depicted in Figure 4C, highlighting regions with varying electron density.

The ligand $\mathbf{L}$ and sodium analog of $\mathbf{L}$ were studied $\mathbf{I n}$ Vitro for the cytotoxic activities against osteoblast U2OS cancerous cells and it was found that $\mathbf{L}$ exhibited a wellbehaved cytotoxicity curve (with an $\mathrm{LD}_{50}$ value of $200 \mu \mathrm{M}$; Figure 5), for the concentration range tested with regards to $\mathbf{1}$, the cytotoxicity survival values never dropped below $60 \%$ (Figure 6). Although the testing of higher concentrations of $\mathbf{1}$ is needed, it may be the case where the structural changes induced by the coordination with sodium may be influencing the cytotoxicity in vivo.

\section{Experimental}

\section{Materials and Methods}

All the manupulations were performed under argon environment using Schlenk line system. 4-hydroxycoumarin (fluka), and benzaldehyde (Sigma Aldrich) were used as received. Analytical grade methanol (Aldrich) was dehydrated and degassed prior to use. Sodium metal (Fluka) was added to methanol to produce sodium methoxide under argon. Elemental analyses were carried out on Varian Elementar II. FT-IR spectra were recorded using Shimadzo FTIR Spectrophotometer Prestige-21. ${ }^{1} \mathrm{H}$ NMR was measured with Bruker DPX $400 \mathrm{MHz}$ (400.23 MHz) whereas, ${ }^{13} \mathrm{C}\left\{{ }^{1} \mathrm{H}\right\} \mathrm{NMR}$ was recorded on Bruker AV $400 \mathrm{MHz}(150.9 \mathrm{MHz})$ spectrometers in DMSO- $d^{6}$ at room temperature. Chemical shifts were reported in ppm and standardized by observing signals for residual protons. Chemical resonances for $\mathbf{L}$ were assigned using structure shown in Scheme 2 and for 1 the resonances were assigned using Figure 1B. Mass spectra were recorded on a LCT Orthogonal Acceleration TOF Electrospray mass spectrometer. Single crystal analyses were carried out using oxford diffractometer. Suitable single crystals for X-ray structural analyses of 1 was mounted on a glass fibre, and the respective data were collected on the diffractometer (graphite-monochromated Mo $\mathrm{K} \alpha$ radiation, $\lambda=0.71073 \AA$ ) at $108(2) \quad K$. The structures were solved with the olex2.solve [47] structure solution program using Charge Flipping and refined with the

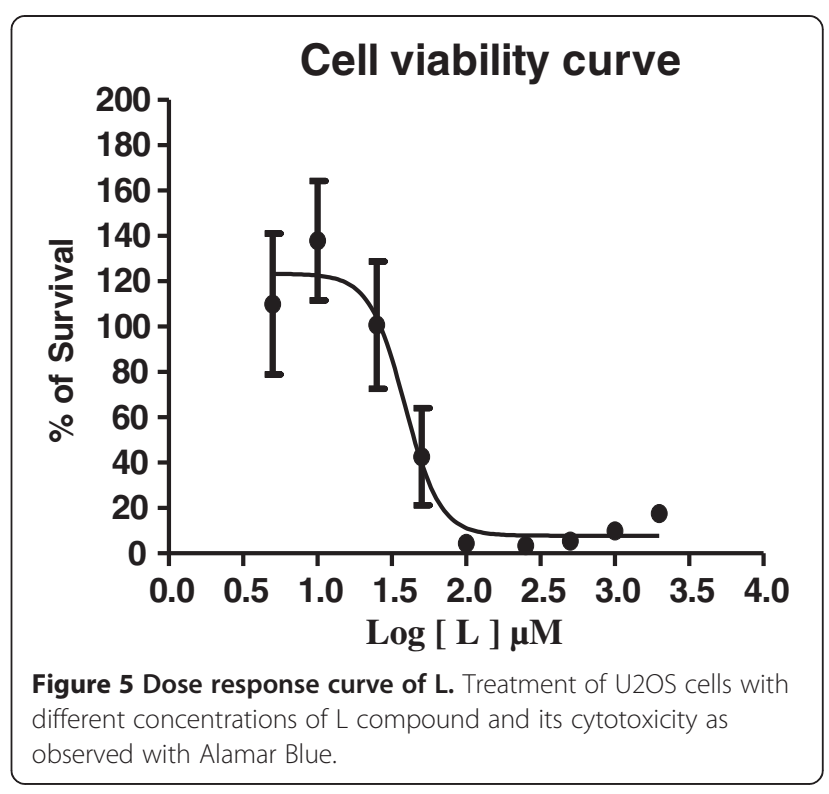

olex2.refine [48] refinement package using Gauss-Newton minimisation. Crystallographic details are given in the Additional file 1. CCDC-868924 (1) data can be obtained free of charge from the Cambridge Crystallographic Data Centre via www.ccdc.cam.ac.uk/ data_request/cif.

The geometric optimization was carried out at the restricted B3LYP [49] hybrid density functional level, as implemented in the G09 program [46]. The X-ray structure was employed as starting configuration for the geometric optimization. The 6-31 $\mathrm{g}(\mathrm{d}, \mathrm{p})$ basis set was assigned to all atoms [50].

\section{Cytotoxic activity}

The human osteosarcoma cell line U2OS was used for testing the tumoricidal activities of the $\mathbf{1}$ and $\mathbf{L}$ compounds. The cells were cultured in DMEM+ GlutaMAXTM-1 with added $1 \%$ penicillin and streptomycin and $10 \%$ heat-inactivated fetal bovine serum. For adherent cells, trypsin-EDTA was used for detachment. The cells were washed in Dulbecco's phosphate buffered saline (DPBS), harvested by centrifugation (1000 rpm, $5 \mathrm{~min}$ ), and resuspended in DMEM. The cells were seeded into 96 -well plates at a density of $5 \times 10^{3}$ cells / well, and incubated at $37^{\circ} \mathrm{C}$ in $5 \% \mathrm{CO}_{2}$ atmosphere for 24 hours before being

Table 1 Comparison of the calculated vs. experimental bond lengths and bond angles for compound 1

\begin{tabular}{|c|c|c|c|c|c|}
\hline Moiety & Theor. bond length, $A^{\circ}$ & Exp. bond length, $A^{\circ}$ & Moiety & Theor. bond angle ${ }^{\circ}$ & Exp. bond angle ${ }^{\circ}$ \\
\hline $\mathrm{Na}-\mathrm{O}$ (coumarin) & $2.40,2.48$ & $2.41,2.47$ & $\mathrm{O}-\mathrm{Na}-\mathrm{O}$ & 80.12 & 89.44 \\
\hline $\mathrm{Na}-\mathrm{O}$ (methanolic) & 2.32 & 2.31 & $\mathrm{Na}-\mathrm{O}$ (methanolic) & $97.08,100.98$ & $100.56,106.33$ \\
\hline
\end{tabular}




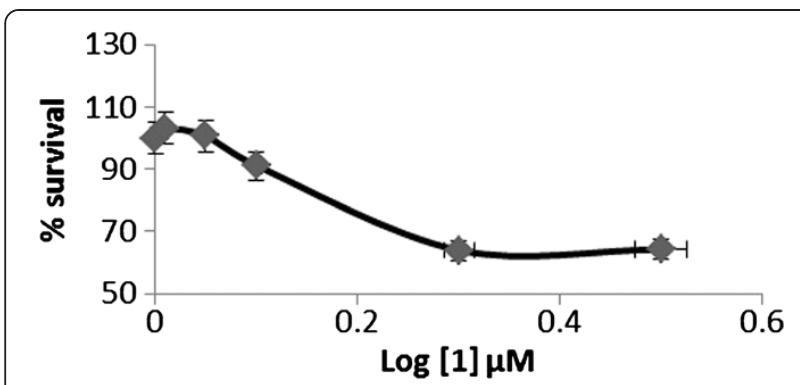

Figure 6 Dose response curve of 1. Treatment of U2-OS cells with different concentrations of 1 compound and its cytotoxicity as observed Alamar Blue.

treated with the compounds. The compounds were initially dissolved at a stock concentration of $10 \mathrm{mM}$ in DMSO and added to wells to a final concentration between 5.0 and $2000 \mu \mathrm{M}$. The plates were then incubated at $37^{\circ} \mathrm{C}$ for a further 24 hours for treatment. Alamar blue (Invitrogen) was used to test the viability of the cells $(10 \mu \mathrm{l}$ per well). Plates in triplicate were incubated for 4 hours at $37^{\circ} \mathrm{C}$ protected from direct light, then read at $590 \mathrm{~nm}$ using an excitation wavelength of $544 \mathrm{~nm}$ in a fluorescence plate reader (Spectra Max Gemini). Wells containing medium and distilled wateronly served as blank controls, while the viability of the treated cells was taken as a percentage compared to wells with untreated cells. The $\mathrm{LD}_{50}$ value of each compound was estimated by fitting the correlation between cell viability and compound concentration.

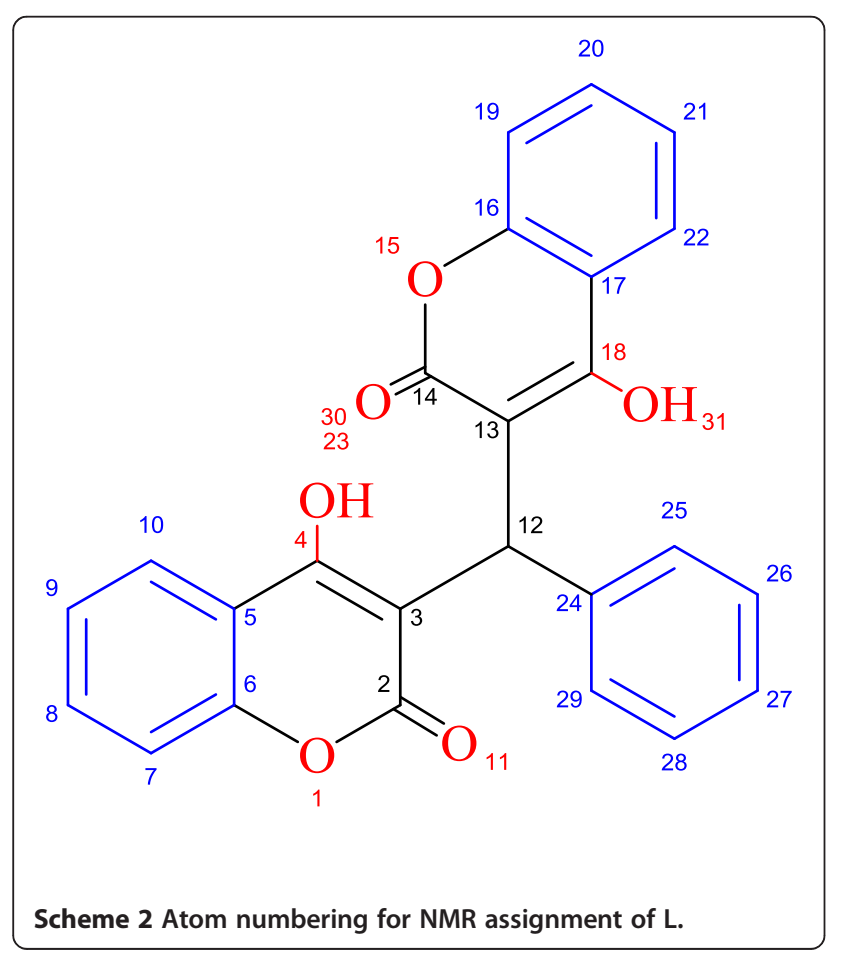

Synthesis of 4-Hydroxy-3-[(4-hydroxy-2-oxo-4a,8a-dihydro2H-chromen-3-yl)-phenyl-methyl]-chromen-2-one (L)

The dicoumarol ligand $(\mathbf{L})$ was synthesized by the reported procedure [51], $25 \mathrm{mmol}$ benazldehyde was added to the $50 \mathrm{mmol}$ stirred ethanolic solution of 4-hydroxycoumarin and the mixture was refluxed for $3 \mathrm{hr}$ at $80^{\circ} \mathrm{C}$. After cooling the reaction mixture, solid white powder of the $\mathbf{L}$ were isolated, washed several times with copious 10\% ethanolic $n$-hexane solution. The product was purified by dissolving in methanolic solution containing small volume of triethylamine. The process repeated two times to get pure recrystalised dicoumarol ligand. Yield: 70\%; m.p. 114. ${ }^{\circ} \mathrm{C}$. IR $\cup\left(\mathrm{cm}^{-1}\right)$ : $3078(\mathrm{OH}) ; 1647(\mathrm{CO}) ; 1562(\mathrm{C}=\mathrm{C})$; 1303 (Lactone C-O). ${ }^{1} \mathrm{H}$ NMR (300 MHz, DMSO- $d^{6}$ ) $(\delta, \mathrm{ppm}): 6.10$ (s, $1 \mathrm{H}, \mathrm{H} 12) ; 7.22-7.67$ (m, 11H, H-arom); 11.34 (s, 2H, OH). ${ }^{13} \mathrm{C}\left\{{ }^{1} \mathrm{H}\right\}-\mathrm{NMR}\left(75.47 \mathrm{MHz}\right.$, DMSO- $\left.d^{6}\right)$ (8, ppm): 36 (C12); 102 (C3, 13); 106 (C27); 116 (C9, 21); 117 (C8, 20); 121 (C26, 28); 123 (C24); 127 (C7, 19); 135 (C4, 18); 152 (C6, 16); 164 (C2, 14). MS, m/ z (\%): $413.1022\left[\mathrm{C}_{25} \mathrm{H}_{16} \mathrm{O}_{6}+\mathrm{H}\right]^{+}(100)$, Elemental Analysis $\left(\mathrm{C}_{25} \mathrm{H}_{16} \mathrm{O}_{6}\right)$, Calc. C: $72.81 \%, \mathrm{H}: 3.91 \%$ Exp. C: 72.83 , $\mathrm{H}: 3.88, \Lambda_{\mathrm{m}}: 240 \mu \mathrm{S}$.

\section{Synthesis of sodium compound of 4-Hydroxy-3-[(4-hydroxy-2-} oxo-4a,8a-dihydro-2H-chromen-3-yl)-phenyl-methyl]-chromen2-one (1)

$10 \mathrm{mmol}$ of the dicoumarol compound was added to $20 \mathrm{~cm}^{3}$ methanol containing $25 \mathrm{mmol}$ of sodium methoxide. The mixture was stirred for about an hour and left over night. Next day transparent block golden X-ray quality single crystals were isolated. Yield: $63 \%$; IR $v\left(\mathrm{~cm}^{-1}\right)$ : 3658 (OH); 1671 (CO); 1534 (C = C); 1349 (Na-O lactone). ${ }^{1} \mathrm{H}$ NMR (400.23 MHz, DMSO- $\left.d^{6}, 303 \mathrm{k}\right)(\delta, \mathrm{ppm}): 2.52$ (s, $\left.12 \mathrm{H}, \mathrm{Na}-\mathrm{OCH}_{3}\right) ; 6.10$ (s, 2H, C6); 7.11-7.67 (m, $26 \mathrm{H}$, Harom); 8.31 (s, 2H, OH); ${ }^{13} \mathrm{C}\left\{{ }^{1} \mathrm{H}\right\}$-NMR $(150.9 \mathrm{MHz}$, DMSO- $d^{6}, 303$ k) ( $\left.\delta, \mathrm{ppm}\right): 33$ (C6); 103 (C5, 7); 106 (C19); 116 (C13, 23); 117 (C14, 23); 121 (C18, 20); 122 (C17, 21); 123 (C16); 131 (C15, 25); 145 (C4, 11); 164 (C2, 9); $167(\mathrm{C} 1,8) .{ }^{23} \mathrm{Na}-\mathrm{NMR}\left(400.23 \mathrm{MHz}, \mathrm{DMSO}-d^{6}\right.$, $303 \mathrm{k})(\delta, \mathrm{ppm}):-1.01 . \mathrm{MS}, \mathrm{m} / \mathrm{z}(\%)$ : No molecular ion peak observed. Elemental Analysis $\left(\mathrm{C}_{54} \mathrm{H}_{44} \mathrm{Na}_{2} \mathrm{O}_{16}\right)$, Calc. C: $65.19 \%, H: 4.46 \%$ Exp. C: $65.23 \%, H: 4.23, \Lambda_{\mathrm{m}}: 410 \mu \mathrm{S}$.

\section{Conclusions}

A sodium analogue (1) with medicinally important dicoumarol ligand (L) has been reported. Spectral analysis and $\mathrm{X}$-ray crystallographic techniques have been used to determine structure of the compound. The crystal structure and DFT study confirm the formation of cationic sodium compound with dicoumarol. The ligand was found more active than the sodium analog attributed to the instability of $\mathbf{1}$ in solution state. Coumarin compound with sodium was observed to be less cytotoxic than the ligand, its $\mathrm{LD}_{50}$ value never dropped below $60 \%$. 


\section{Additional file}

\section{Additional file 1: Supporting Information.}

\section{Competing interests}

The authors declare that they have no competing interests.

\section{Authors' contributions}

$\mathrm{SR}$ and $\mathrm{MI}$ carried out the original laboratory work in the lab. of RJB under the supervision of SUR. EA, SM and KHM analysed the samples for their U2OS anticancer studies. AK and TSH carried out the theoretical studies. The structure was solved by SR and AJB. All authors read and approved the final manuscript.

\section{Acknowledgement}

The authors S. Rehman and M. Ikram gratefully acknowledge the Higher Education Commission (HEC) Pakistan for financial support

\section{Author details}

${ }^{1}$ Institute of Chemical Sciences, University of Peshawar, Peshawar, Pakistan. ${ }^{2}$ Department of Chemistry, Sarhad University of Science and Information Technology, Peshawar, Pakistan. ${ }^{3}$ Institute of General, Inorganic and Theoretical Chemistry, University of Innsbruck Innrain 80-82, A-6020 Innsbruck, Austria. ${ }^{4}$ Trinity Biomedical Sciences Institute (TBSI) School of Biochemistry and Immunology Trinity College, Dublin 2, Ireland. ${ }^{5}$ School of Chemistry, University of Dublin Trinity College, Dublin 2, Ireland. ${ }^{6}$ School of Chemistry, The University of Nottingham, Nottingham NG7 2RD, UK.

Received: 16 March 2013 Accepted: 13 June 2013

Published: 2 July 2013

\section{References}

1. Osuna D, de Alava E: Molecular Pathology of Sarcomas. Rev Recent Clin Trials 2009, 4(1):12-26.

2. Coindre JM: Grading of soft tissue sarcomas: review and update. Arch Pathol Lab Med 2006, 130(10):1448-1453.

3. Weiss RB: The anthracyclines: will we ever find a better doxorubicin? Semin Oncol 1992, 19(6):670-686.

4. Bloch R, Bloch A: "25 Most Asked Questions". ebook versionth edition. Missouri: Fighting Cancer, R. A. Bloch Cancer Foundation; 2011.

5. Groopman JE: How Doctors Think. Boston: Houghton Mifflin; 2007. p. 49.

6. Yeo W, Lam KC, Zee B: Hepatitis B reactivation in patients with hepatocellular carcinoma undergoing systemic chemotherapy. Ann Oncol 2004, 15(11):1661-1666.

7. Dillon R, Hirschfield GM, Allison ME, Rege KP: Fatal reactivation of hepatitis B after chemotherapy for lymphoma. BMJ 2008, 337:39490.

8. Ajithkumar T, Parkinson C, Shamshad F, Murray P: Ifosfamide encephalopathy. Clin Oncol (R CollRadiol) 2007, 19(2):108-114.

9. Finn GJ, Creaven BS, Egan DA: Activation of mitogen activated protein kinase pathways and melanogenesis by novel nitro-derivatives of 7-hydroxycoumarin in human malignant melanoma cells. Eur J Pharm Sci 2005, 26:16-25.

10. Kolodziej H, Kayser O, Woerdenbag HJ, Van Ulden W, Pras N: Structurecytotoxicity relationships of a series of natural and synthetic simple coumarins as assessed in two human tumor cell lines. Naturforsch 1997, $52: 240-244$.

11. Jimenez-Orozco FA, Molina-Guarneros JA, Mendoza- Patino N, Leon-Cedeno F, Flores-Perez B, Santos-Santos E, Mandoki JJ: Cytostatic activity of coumarin metabolites and derivatives in the B16-F10 murine melanoma cell line. Melanoma Res 1999, 9:243-247.

12. Bedair AH, El-Hady NA, Abd El-Latif MS, Fakery AH, El-Agrody AM: 4Hydroxycoumarin in heterocyclic synthesis. Part III: synthesis of some new pyrano[2,3-d][1,2,4]-triazolo[1,5-c]pyrimidine and pyrimido[1,6-b] $[1,2,4]$ triazine derivatives. // Farmaco 2000, 55:708-714

13. Laurin $\mathrm{P}$, Klich M, Dupis-Hamelin C, Mauvais $\mathrm{P}$, Lassaigne $\mathrm{P}$, Bonnefoy $\mathrm{A}$ Musicki B: Synthesis and in vitro evaluation of novel highly potent coumarin inhibitors of gyrase B. Bioorg Med Chem Lett 1999, 9:2079-2084.

14. Hoult RJS, Paya M: Pharmacological and biochemical actions of simple coumarins: natural products with therapeutic potential. Gen Pharmacol 1996, 27:713-722.
15. Pillai SP, Menon SR, Mitscher LA, Pillai CA, Shankel DA: Umbelliferone analogues and their potential to inhibit Benzo(a)pyrene- and hydrogen peroxide-induced mutations. J Nat Prod 1999, 62:1358-1362.

16. Kimura Y, Okuda H, Arichi S, Baba K, Kozawa M: Effects of stilbenes on arachidonate metabolism in leukocytes. Biochim Biophys Acta 1985, 834:275-278.

17. Hoffmanova J, Kozubik A, Dusek L, Pachernik J: Inhibitors of lipoxygenase metabolism exert synergistic effects with retinoic acid on differentiation of human leukaemia HL-60 cells. Eur J Pharmacol 1998, 350:273-284.

18. Sadia R, Muhammad I, Baker RJ, Muhammad Z, Effat A, Soyoung M, Kashif R, Mok KH, Saeed-Ur R: Synthesis, characterization, in vitro antimicrobial, and U2OS tumoricidal activities of different coumarin derivatives. Chem Cent J 2013, 7(1):68.

19. Sharma S, Stutzman D, Kellof JG, Steele VE: Screening of potential chemopreventive agents using biochemical markers of carcinogenesis. Cancer Res 1994, 54:5848-5855.

20. Egan D, James P, Cooke D, O'Kennedy R: Studies on the cytostatic and cytotoxic effects and mode of action of 8-nitro-7-hydroxycoumarin. Cancer Lett 1997, 118:201-211.

21. Hayes JD, Pulford DJ, Ellis EM, McLeod R, James RFL, Seidegard J, Mosialou

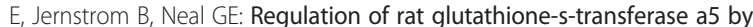
cancer chemopreventive agents - mechanisms of inducible resistance to Aflatoxin B-1". Chem Biol Interact 1998, 111:51-67.

22. Finn GJ, Creaven BS, Egan DA: Investigation of intracellular signaling events mediating the mechanism of action of 7-hydroxycoumarin and 6-nitro-7hydroxycoumarin in human renal cells. Cancer Lett 2004, 205:69-79.

23. Finn GJ, Creaven BS, Egan DA: Daphnetin induced differentiation of human renal carcinoma cells and its mediation by p38 mitogenactivated protein kinase. Biochem Pharmacol 2004, 67:1779-1788.

24. Xin Zhang C, Lippard S: New metal complexes as potential therapeutics. Curr Opin Chem Biol 2003, 7:481-489.

25. Sakurai H, Kojima Y, Yoshikawa Y, Kawabe K, Yasui H: Antidiabetic vanadium(IV) and zinc(II) complexes. Coord Chem Rev 2002, 226:187-198.

26. Sadler PJ, Li H, Sun H: Coordination chemistry of metals in medicine: target sites for bismuth. Coord Chem Rev 1999, 185:689-709.

27. Ali H, van Lier JE: Metal complexes as photo- and radiosensitizers. Chem Rev 1999, 99:2379-2450.

28. Louie AY, Meade TJ: Metal complexes as enzymetic inhibitors. Chem Rev 1999, 99:2711-2734.

29. Volkert WA, Hoffman TJ: Therapeutic radiopharmaceuticals. Chem Rev 1999, 99:2269-2292.

30. Grotz KA, Wustenberg P, Kohnen R, Al-Nawas B, Henneicke-von Zepelin HH, Bockisch A: Prophylaxis of radiogenic sialadenitis and mucositis by coumarin/troxerutine in patients with head and neck cancer-a prospective, randomized, placebo-controlled, double-blind study. $\mathrm{Br} J$ Oral Maxillofac Surg 2001, 39:34-39.

31. Weislo G, Szezylik C: In process citation. Pol Merkuriusz Lek 2003, 15:5-8.

32. Thornes RD, Edlow DW, Wood S Jr: Inhibition of locomotion of cancer cells in vivo by anticoagulant therapy. I. Effects of sodium warfarin on V2 cancer cells, granulocytes, lymphocytes and macrophages in rabbits. Johns Hopkins Med J 1968, 123:305-316.

33. Finn GJ, Creaven BS, Egan DA: Study of the in vitro cytotoxic potential of natural and synthetic coumarin derivatives using human normal and neoplastic skin cell lines. Melanoma Res 2001, 11:461-476.

34. Marshall ME, Mendelsohn L, Butler K, Riley L, Cantrell J, Wiseman C, Taylor R, Macdonald JS: Treatment of metastatic renal cell carcinoma with coumarin (1,2- benzopyrone) and cimetidine: a pilot study. Am Soc Oncol 1987, 5:862-866.

35. Marshall ME, Ryles M, Butler K, Weiss L: Treatment of advanced renal cell carcinoma (RCC) with coumarin and cimetidine: longterm follow-up of patients treated on a phase I trial. J Cancer Res Clin Oncol 1994, 120:535-538.

36. Myers RB, Parker M, Grizzle WE: The effects of coumarin and suramin on the growth of malignant renal and prostatic cell lines. J Cancer Res Clin Oncol 1994, 120:S11-S13.

37. Wang CJ, Hsieh YJ, Chu CY, Lin YL, Tseng TH: Inhibition of cell. Cycle progression in human leukemic HL-60 cells by esculetin. Cancer Letts 2002, 160:107-113.

38. Jimenz-Orozco F, Lopez-Gonzalez JS, Nieto-Rodriguez A, Velasco-Velazquez MA, Molina-Guarneros JA, Mendoza-Patino N: Decrease of cyclin D1 in the human lung adenocarcinoma cell line A-427 by 7-hydroxycoumarin. Lung Cancer 2001, 34:185-194. 
39. Spirk S, Belaj F, Kahr J, Pietschnig R: A one dimensional coordination polymer formed by a 2:1 adduct of trifluoroacetic acid and its sodium salt. J Fluorine Chem 2009, 130:365-367.

40. Binev $\mathrm{YI}$, Binev IG, Juchnovski IN: The formation and isomerization of the sodium methoxide adducts of cinnamylidenemalononitrile, followed by IR spectra and ab initio force field calculations. J Mol Struc-Theochem 2000, 532:31-36.

41. Rabe GW, Liable-Sands LM, Rheingold AL: Synthesis of sodium 2,6dimesitylphenyl phosphanide and X-ray crystal structure determination of its 15-crown-5 adduct. Inorg Chim Acta 2002, 329:151-154.

42. Mukherjee P, Drew MGB, Figuerola A, Ghosh A: Incorporation of a sodium ion guest in the host of copper(II)-Schiff-base complexes: structural characterization and magnetic study. Polyhedron 2008, 27:3343-3350.

43. Arias J, Bardaji M, Espinet P: Tris-(1,2-N,N-dimethylaminomethylferrocenyl) stibine and its heterotrimetallic complex. J Organomet Chem 2006, 691:4990-4999.

44. Blaurock S, Edelmann FT, Haiduc I, Mezei G, Poremba P: Dimeric thiophosphorus complexes of sodium and zinc: structural characterization of $\left[(\mathrm{THF})_{2} \mathrm{NaO}(\mathrm{S}) \mathrm{PPh}_{2}\right]_{2}$ and $\left[\mathrm{Zn}\left\{\mathrm{S}_{2} \mathrm{P}(\mathrm{OMe}) \mathrm{C}_{6} \mathrm{H}_{4} \mathrm{OEt}-\mathrm{p}\right\}_{2}\right]_{2}$. Inorg Chim Acta 2008, 361:407-410.

45. Becke AD: Density-functional thermochemistry. III. The role of exact exchange. J Chem Phys 1993, 98:5648-5652.

46. Frisch MJ, Trucks GW, Schlegel HB, Scuseria GE, Robb MA, Cheeseman JR, Scalmani G, Barone V, Mennucci B, Petersson GA, Nakatsuji H, Caricato M, Li X, Hratchian HP, Izmaylov AF, Bloino J, Zheng G, Sonnenberg JL, Hada M, Ehara M, Toyota K, Fukuda R, Hasegawa J, Ishida M, Nakajima T, Honda Y, Kitao O, Nakai H, Vreven T, Montgomery JAJ, et al.: Gaussian 09, Revision A.02. Wallingford, CT: Gaussian, Inc; 2009.

47. Dolomanov OV, Bourhis LJ, Gildea RJ, Howard JAK, Puschmann H: OLEX2: a complete structure solution, refinement and analysis program. J Appl Cryst 2009, 42:339-341.

48. olex2.refine, Bourhis L, Dolomanov OV, Gildea RJ, Howard JAK, Puschmann $\mathrm{H}$ : in preparation. 2011.

49. Dias HVR, Goh TKHH: Fluorinated Tris(pyrazolyl)borates. Syntheses and characterization of sodium and copper complexes of [HB(3-(CF3),5-(Ph) Pz)3]. Polyhedron 2004, 23:273-282.

50. Hehre WJ, Ditchfield R, Pople JA: Self—consistent molecular orbital methods. XII. Further extensions of Gaussian - type basis sets for use in molecular orbital studies of organic molecules. J Chem Phys 1972, $56: 2257-2261$

51. Rehman S, Ikram M, Baker R J, Zubair M, Azad E, Min S, Riaz K, Mok KH, Rehman S: Synthesis, characterization, in vitro antimicrobial, and U2OS tumoricidal activities of different coumarin derivatives. Chemistry Central Journal 2013 7:68.

doi:10.1186/1752-153X-7-110

Cite this article as: Rehman et al: New dicoumarol sodium compound: crystal structure, theoretical study and tumoricidal activity against osteoblast cancer cells. Chemistry Central Journal 2013 7:110.

Publish with ChemistryCentral and every
scientist can read your work free of charge
"Open access provides opportunities to our
colleagues in other parts of the globe, by allowing
anyone to view the content free of charge."
W. Jeffery Hurst, The Hershey Company.
- available free of charge to the entire scientific community
- peer reviewed and published immediately upon acceptance
- cited in PubMed and archived on PubMed Central
- yours - you keep the copyright
Submit your manuscript here:
htpp://www.chemistrycentral.com/manuscript/

